\title{
Medicinal chemistry and the Bachelor of Pharmacy curriculum: Assessment of student's perspectives, needs and barriers
}

\author{
Adel Ardakani ${ }^{1}$, Iman A Basheti ${ }^{2 *}$ \\ ${ }^{1}$ Department of Pharmaceutical Chemistry and Pharmacognosy, ${ }^{2}$ Department of Clinical Pharmacy and Therapeutics, Faculty \\ of Pharmacy, Applied Science Private University, Amman, Jordan \\ *For correspondence: Email: dr_iman@asu.edu.jo; Tel: +962 799048003
}

Sent for review: 9 December 2017

Revised accepted: 24 April 2018

\begin{abstract}
Purpose: To identify students' perspectives, needs and barriers faced when studying medicinal chemistry (MC).

Methods: A validated questionnaire was designed to explore pharmacy students understanding of $M C$ courses and their learning outcomes as it relates to the pharmacy degree, as well as identify the barriers leading to their under-performance in examinations. All fourth year MC students were asked to answer the questionnaire. Data was entered into SPSS and analyzed.

Results: One hundred and forty-nine students (97 female and 52 males) in the age range of $20-23$ years old completed the questionnaire. A majority of the students (66\%) agreed that MC is an important topic, while $52.7 \%$ indicated that it meets the objectives stated. Just over a quarter of the students $(26.2$ \%) chose to pursue a career or a postgraduate study related to MC. Students who perceived MC as a 'dry' topic (40.3\%) with course objectives/learning outcomes being unclear had negative perceptions regarding $M C$ being an important topic for the pharmacy profession.

Conclusion: Although pharmacy students believe that MC is an important topic for the pharmacy profession, many feel that the current courses provided do not meet its main objective. Despite all barriers revealed in this study regarding students studying $M C$, a good number of students look forward to pursuing a career/ postgraduate study related to MC.
\end{abstract}

Keywords: Medicinal chemistry, Pharmacy education, Undergraduate education, Educational barriers

\begin{abstract}
This is an Open Access article that uses a funding model which does not charge readers or their institutions for access and distributed under the terms of the Creative Commons Attribution License (http://creativecommons.org/licenses/by/4.0) and the Budapest Open Access Initiative (http://www.budapestopenaccessinitiative.org/read), which permit unrestricted use, distribution, and reproduction in any medium, provided the original work is properly credited.
\end{abstract}

Tropical Journal of Pharmaceutical Research is indexed by Science Citation Index (SciSearch), Scopus, International Pharmaceutical Abstract, Chemical Abstracts, Embase, Index Copernicus, EBSCO, African Index Medicus, JournalSeek, Journal Citation Reports/Science Edition, Directory of Open Access Journals (DOAJ), African Journal Online, Bioline International, Open-J-Gate and Pharmacy Abstracts

\section{INTRODUCTION}

The Joint Commission of Pharmacy Practitioners' Vision Statement for Pharmacy Practice in 2015 states that 'Pharmacist will be a health care professional responsible for providing patient care that ensures optimal medication outcomes' [1]. The cornerstone of achieving this vision is the redirection of pharmaceutical practice from drug-based to patient-based practice. The importance of this transition has been recognised as early as the mid of 1960s [2]; however, the success of this transition called upon the different pharmacy organisations and educational institutions for support [3]. In concordance with this trend, the Accreditation Council for 
Pharmacy Education Standards and Guidelines has recently stated that pharmacy courses should involve actual hands on experiences that link the education received to the real pharmacy world with which the students will be engaged following graduation [4].

In Jordanian Universities, a five-year pharmacy program that follows an adapted American credit hours system is functional, with the Bachelor in Pharmacy degree obtained after successful passing $161 \pm 5$ credit hours with a Grade point average (GPA) above $60 \%$ as a requirement. Some universities offer the Doctor of Pharmacy program, while most, including Applied Science Private University offer the Bachelor in Pharmacy degree $[5,6]$. Medicinal Chemistry $(\mathrm{MC})$ is a main part in the Bachelor in Pharmacy degree as well as in the Doctor of Pharmacy degree, and plays an important role in the evolution of pharmacy profession, not only as a basic science, but as a tool to understand drug action and behavior within the human body [7]. These concepts render MC among the most difficult courses for pharmacy students. MC courses are offered for third year students as MC 1 followed by MC 2, and ends with a drug design course in their fourth year. Organic chemistry, physical pharmacy and microbiology are prerequisite courses covered in the first two years prior to taking medicinal chemistry courses. It is worth mentioning that taking the prerequisite is required while successfully completing it is not a must. In addition, pharmacology courses are given concomitantly with medicinal chemistry during third and fourth year of study in expectation to connect these important pharmacy courses together [8].

At Applied Science Private University (ASU), as educators we know that students perceive $M C$ as a dry course and miss realizing the connection between it and the eventual aim of the pharmacy degree they are studying. This leads to a disconnection between the lecture room and the real pharmacy world leading to students' lack of interest in attending the lectures. Through previous course evaluations, students have consistently expressed dissatisfaction with the difficulty of the MC courses, lack of actual hands on education and clear connection with other pharmacy courses they take during their study. Also, the high failure rates and high proportion of students obtaining low grades (50 - $59 \%$ ) across the different cohorts, highlighted the importance of investigating reasons and advising resolutions to this long standing problem. Hence, the instructors of the $\mathrm{MC}$ courses decided to conduct a cross sectional study with the aim of exploring students' perspectives toward the core values of medicinal chemistry as part of the Bachelor of Pharmacy curriculum and pharmacy profession. Secondly, to reveal different factors that could be playing a role in creating such perspectives.

\section{METHODS}

\section{Study design}

This was a prospective investigational study that was approved by the ASU Faculty of Pharmacy Ethics Committee (ethics approval no. 11/2016/2017). Administrative approval was also obtained for the study from the Faculty of Pharmacy. The study protocol was conducted in agreement with the World Medical Association Declaration of Helsinki guidelines [9]. The study was conducted during the autumn semester of 2016, after students' completed both MC 1 and MC 2 courses and their final course results were evaluated and compared with their preparation for $M C$ and study findings.

All students $(n=149)$ were invited to participate in the study and were informed of the anonymous nature of the survey and the results, and the fact that it will be only used for scientific reasons, as well as to allocate the best approaches to improve student experience in the $\mathrm{MC}$ courses. Students were given the choice to participate in this study and if they agreed they were asked to sign the informed consent form before study enrollment.

\section{Course history}

Pharmacy faculty members at the ASU designed the $M C$ course for students to learn how to recognize the drugs affecting different targets or receptors and to identify the categories of certain classes of drugs and their structure activity relationships. The course was run over two semesters in the third year (midway through their degree) were students attended 42 lectures over 14 weeks each semester. The course assessment involved a multiple choice with short essay questions exam twice during the semester and a final exam at the end of the semester. Content knowledge related to medicinal chemistry knowledge was delivered by one of the researchers (AA, the course instructor) providing the information needed to cover to sit for the course exams.

Course outcomes were developed to reveal the value of the education delivered during the two MC courses. The learning objectives of the courses included: 1. Gain an appreciation for how the structure of a drug relates to its activity and how basic research into the biochemical 
mechanism of disease leads to the targeted development of drugs. 2. Learn the influence of the physio-chemical properties of a drug on its absorption, distribution and elimination. 3 . Understand the chemical basis of drug action at molecular level and drug metabolism pathways and the reasons for pro-drugs. 4. Recognize structure activity relationship (SAR) of major drug groups and their relation to mechanism of action (MOA) in different systems.

The instructional design model involving analysis, design, development, implementation and evaluation (ADDIE) [10] was decided to be used as the framework in redesigning the course based on the results provided by the students.

\section{Questionnaire and data collection}

A structured questionnaire was designed to collate data regarding the students' perspectives, needs and barriers towards learning MC. To ensure face validity, this questionnaire was evaluated prior to the current study by five academics that have extensive experience in conducting research studies in the pharmacy education area, and a wide range of professional pharmacy experience. The questionnaire was administered to a random sample of pharmacy students $(n=15)$ to test for the clarity of its items. Views and comments of those students were analyzed by the researchers and then incorporated, where appropriate, into the final version of the questionnaire used in this study.

\section{The questionnaire was administered during the drug design course taken by MC students in the fall semester upon completion of both MC1 and MC2 prerequisite courses}

The survey consisted of 15 items categorized into three separate parts; Part A investigated student demographics, including year level in pharmacy, gender, type of high school, English language evaluation, community pharmacy training or work with a number of hours and teaching techniques used during MC courses. Part B investigated the core values of $\mathrm{MC}$ as part of the Bachelor of Pharmacy curriculum and pharmacy profession, for example, importance of MC, whether it helps better understand other courses, and whether it consists of clear objectives. Part C looked into the educational resources, methods and assessment. Part D focused on the learning barriers faced by the students.

A section for students' comments was allocated for students to write extra information if needed at the end of Parts A, B and C.

\section{Focus group}

At the end of the course, an open invitation was extended to students to attend a focus group session to elicit comments about the MC courses. A series of open-ended questions were prepared by the investigators as a basis for the semi-structured interview format, and the session was facilitated by one of the investigators (AA). The questions were:

1- According to your knowledge, how strongly is medicinal chemistry related to your pharmacy profession?

2- What motivated you to study Medicinal Chemistry?

3- What study approaches did you use to prepare yourself to answer the medicinal chemistry exam questions?

4- Were the organic chemistry prerequisite courses enough to prepare you for the medicinal chemistry courses?

5- With regards to exams, what changes would you recommend in order to increase the passing rates in medicinal chemistry courses?

6- What educational strategies would you suggest to help you better excel at medicinal chemistry?

\section{Data analysis}

The data was analyzed using the Statistical Package for Social Science (SPSS) version 20. Data including gender, age, hours spent in pharmacy training, years spent in undergraduate pharmacy studies, type of high-school attended, and English level were analyzed descriptively. The mean $\pm S D$ and the $95 \%$ confidence interval (Cl) were used to describe the normally distributed continuous data (normality of distribution was determined using the Kolmogorov-Smirnov test). For non-normally distributed data, non-parametric tests were used (Friedman test for comparisons of scores within group, and Mann Whitney U test for comparisons between groups). Proportional data was analyzed using Pearson's Chi-Square test (or Fisher's exact test). For all statistical analysis, $p$ $\leq 0.05$ was considered statistically significant.

In order to determine the predictors of students' perception regarding $\mathrm{MC}$ being an important topic for their pharmacy profession, a backwards multiple regression analysis was performed. The dependent variable was students' perception 
regarding MC. The independent variables included gender, age, pharmacy experience (hours), previous work in community pharmacy (yes/no), type of high-school attended, and student reported English level.

Data from the recording of Focus group conversations were summarized thematically.

\section{RESULTS}

One hundred and forty-nine students (97 female and 52 males) with an average age range of 20 23 years participated in this survey (Table 1 ). The majority of the students $(121,81.2 \%)$ were in their fourth-year, few were in their third $(4,2.7$ $\%)$ or fifth-year $(24,16.1 \%)$ of the pharmacy program. Most of the students attended school outside of Jordan $(69,46.3 \%$ ) while $30.8 \%$ attended schools in Jordan. Students believed that they had intermediate English level (56.5\%) to advanced English level (30.6\%). Majority $(88.4 \%)$ reported lectures as the most common teaching technique used during their $\mathrm{MC}$ courses (Table 1). Most of the students $(130,87.2 \%)$ had community pharmacy practice.

Students start pharmacy training as part of their degree studies at the end of their second-year; thus, the majority of students has training in a community pharmacy (87.8\%). About $30.8 \%$ of the student had their high school education from Jordanian schools while $69.1 \%$ studied in nonJordanian schools. Over half of the student sample $(56.5 \%)$ assessed proficiency in their written English language as intermediate and $(30.6 \%)$ as advanced, we should mention that all notes, textbooks and exams are written in the English language. The number of hour in pharmacy training / working varies from a minimum of $8 \mathrm{~h}$ up to a maximum of $1720 \mathrm{~h}$ as some students continue their pharmacy Bachelor degree after obtaining the pharmacy diploma and possibly working for a number of years. The mean number of hours for this group was 568.5 h. Lecturing was the most frequent teaching technique used with the students at the pharmacy faculty, an example of another learning technique is the six office hours open weekly for students to walk in and ask their questions.

Majority of the students (66 \%) agree that medicinal chemistry is an important topic and studying it helps to better understand related topics in their pharmacy education (Table 2).

Just over half the students (52.7\%) agree that MC courses have met their objectives, when looking at one main objective of medicinal chemistry, which is recognizing active pharmaceutical ingredient structures affecting different pharmacological targets, majority of the students $(62 \%)$ reported that they failed meeting this objective using the current educational methodologies. When comparing the percentage of students unable to pass this course based on their final course results at the end of each semester, there is a positive correlation with the number of students who disagreed with the above mentioned objective $(26.6 \%)$; the fail rate for MC1 was $14.4 \%$ and for MC2 was $22 \%$. Just over a quarter of the student sample (26.2 \%) agreed to pursue a career or a postgraduate study related to medicinal chemistry.

A third of the students (31.3\%) agreed to selfstudy from textbook and to present an assignment in class, while just more than a third $(35.8 \%)$ agreed to evaluate other student's learning such as carrying out peer assessments. Multiple choice questions is the major examination tool used to evaluate these students knowledge as well as some short essay type questions due to the chemistry nature of these courses and the appropriate drawing of certain active ingredient chemical structures.

Table 1: Characteristics and demographic information for study participants $(n=149)$

\begin{tabular}{|c|c|c|c|c|c|}
\hline Variable & & Stude & characteristics a & d choices & \\
\hline $\begin{array}{l}\text { Type of high-school } \\
\text { student graduated from. } \\
n(\%)\end{array}$ & $\begin{array}{l}\text { Jordan public } \\
\text { school } \\
6(4.1 \%)\end{array}$ & $\begin{array}{l}\text { Jordan } \\
\text { private } \\
\text { school }\end{array}$ & $\begin{array}{l}\text { Arab public } \\
\text { school }\end{array}$ & $\begin{array}{l}\text { Arab private } \\
\text { school }\end{array}$ & Other \\
\hline $\begin{array}{l}\text { Student evaluation of } \\
\text { his/her written English } \\
\text { language level. } \\
\text { n (\%) }\end{array}$ & $\begin{array}{l}\text { Fundamental } 1 \\
(0.7 \%)\end{array}$ & $\begin{array}{l}39(26.7 \%) \\
\text { Novice } \\
5(3.4 \%)\end{array}$ & $\begin{array}{l}37(25.3 \%) \\
\text { Intermediate } 83 \\
(56.5 \%)\end{array}$ & $\begin{array}{l}32(21.9 \%) \\
\text { Advanced } \\
45(30.6 \%)\end{array}$ & $\begin{array}{l}32(21.9 \%) \\
\text { Expert } \\
13(8.8 \%)\end{array}$ \\
\hline $\begin{array}{l}\text { Reported teaching } \\
\text { techniques used during } \\
\text { medicinal Chemistry } \\
\text { courses. } \\
\text { n (\%) }\end{array}$ & $\begin{array}{l}\text { Lectures } \\
130(88.4 \%)\end{array}$ & $\begin{array}{l}\text { Tutorials } \\
6(4.1 \%)\end{array}$ & $\begin{array}{l}\text { Role playing } 1 \\
(0.7 \%)\end{array}$ & $\begin{array}{l}\text { Clinical cases } \\
3(2.0 \%)\end{array}$ & $\begin{array}{l}\text { Other } \\
7(4.8 \%)\end{array}$ \\
\hline
\end{tabular}


Table 2: Student opinions $(n=149)$ regarding medicinal chemistry courses

\begin{tabular}{|c|c|c|c|c|c|}
\hline Item & $\begin{array}{l}\text { Strongly } \\
\text { agree }\end{array}$ & Agree & Neutral & Disagree & $\begin{array}{l}\text { Strongly } \\
\text { disagree }\end{array}$ \\
\hline $\begin{array}{l}\text { Medicinal chemistry is an important topic for } \\
\text { your profession }\end{array}$ & $\begin{array}{l}25 \\
(16.9 \%)\end{array}$ & $\begin{array}{l}74 \\
(50.0 \%)\end{array}$ & $\begin{array}{l}38 \\
(25.7 \%)\end{array}$ & 8 (5.4\%) & $\begin{array}{l}3 \\
\\
(2.0 \%)\end{array}$ \\
\hline $\begin{array}{l}\text { Medicinal chemistry courses help to better } \\
\text { understand other pharmacy courses in your } \\
\text { degree }\end{array}$ & $\begin{array}{l}16(10.8 \\
\%)\end{array}$ & $\begin{array}{l}82(55.4 \\
\%)\end{array}$ & $\begin{array}{l}41(27.7 \\
\%)\end{array}$ & $\begin{array}{l}9 \\
(6.1 \%)\end{array}$ & 0 \\
\hline $\begin{array}{l}\text { Current medicinal chemistry courses are } \\
\text { successful in meeting its objectives? }\end{array}$ & $\begin{array}{l}6 \\
(4.1 \%)\end{array}$ & $\begin{array}{l}72(48.6 \\
\%)\end{array}$ & $\begin{array}{l}58(39.2 \\
\%)\end{array}$ & $10(6.8 \%)$ & $\begin{array}{l}2 \\
(1.4 \%)\end{array}$ \\
\hline $\begin{array}{l}\text { You can easily recognize active } \\
\text { pharmaceutical ingredient structures affecting } \\
\text { different targets using the educational } \\
\text { methodologies learnt in your course }\end{array}$ & 6 & $\begin{array}{l}50(34.0 \\
\%)\end{array}$ & $\begin{array}{l}52(35.4 \\
\%)\end{array}$ & $\begin{array}{l}37(25.2 \\
\%)\end{array}$ & $(1.4 \%)$ \\
\hline $\begin{array}{l}\text { Studying pharmacology is essential prior to } \\
\text { medicinal chemistry to better understand } \\
\text { these medicinal chemistry courses }\end{array}$ & $\begin{array}{l}18(12.1 \\
\%)\end{array}$ & $\begin{array}{l}69(46.3 \\
\%)\end{array}$ & $\begin{array}{l}26(17.4 \\
\%)\end{array}$ & $\begin{array}{l}29(19.5 \\
\%)\end{array}$ & $\begin{array}{l}7 \\
(4.7 \%)\end{array}$ \\
\hline $\begin{array}{l}\text { You would seek a career / post graduate } \\
\text { studies specially related to medicinal } \\
\text { chemistry }\end{array}$ & $\begin{array}{l}7 \\
(4.8 \%)\end{array}$ & $3121.4 \%)$ & $\begin{array}{l}43(29.7 \\
\%)\end{array}$ & $\begin{array}{l}41(28.3 \\
\%)\end{array}$ & $\begin{array}{l}23(15.9 \\
\%)\end{array}$ \\
\hline $\begin{array}{l}\text { Take on the task of reading from textbook or } \\
\text { a research paper regarding Medicinal } \\
\text { Chemistry and present it in class }\end{array}$ & $\begin{array}{l}8 \\
(5.4 \%)\end{array}$ & $\begin{array}{l}38(25.9 \\
\%)\end{array}$ & $\begin{array}{l}55(37.4 \\
\%)\end{array}$ & $\begin{array}{l}41(27.9 \\
\%)\end{array}$ & $\begin{array}{l}5 \\
(3.4 \%)\end{array}$ \\
\hline $\begin{array}{l}\text { Would you participate in evaluating other } \\
\text { student's learning (peer Assessment) }\end{array}$ & $\begin{array}{l}6 \\
(4.1 \%)\end{array}$ & $\begin{array}{l}46(31.7 \\
\%)\end{array}$ & $\begin{array}{l}43(29.7 \\
\%)\end{array}$ & $\begin{array}{l}42(29.0 \\
\%)\end{array}$ & $\begin{array}{l}8 \\
(5.5 \%)\end{array}$ \\
\hline
\end{tabular}

The highest preferred method of assessment preferred by the students is open book $(37.8 \%)$ while written assignments came in second (22.3 $\%$, Figure 1).

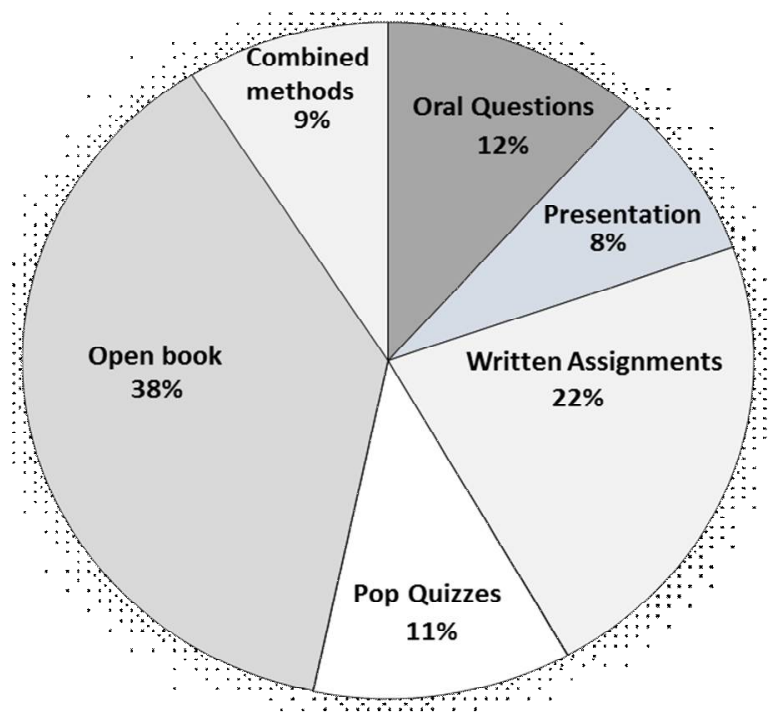

Figure 1: Method of assessments chosen by the students who participated in this study $(n=149)$ in addition to the standard multiple-choice questions

There was a significant difference in gender regarding taking on the task of reading from a textbook or research paper and presenting it in class, $(40 \%)$ of males agree compared to (26.8 $\%$ ) of females. Table 3 shows the learning barriers faced by the students in studying medicinal chemistry.
Significant correlation was found between students reported believes regarding medicinal chemistry being an important topic for their profession and inability to relate $\mathrm{MC}$ to the pharmacy profession $(r=0.312, p<0.001$, Pearson correlation).

Logistic regression modeling the dependent variable 'student believe regarding $M C$ being an important topic for their pharmacy profession (R2 $=0.225, p<0.001$ ), indicated that reporting that $\mathrm{MC}$ is a dry topic and course objectives/learning outcomes being unclear were the variable showing significant association with the dependent variable (Table 4).

\section{Focus group findings}

The Focus group discussion $(n=15)$ showed that students consider medicinal chemistry as related to drug design courses and the invention of new drugs. However, the majority felt that job opportunities in this part of the world (Jordan and the Middle East) revolve mostly around marketing, generating a lack of interest in these topics. Motivation to study MC was found to be highly dependent on the lecturer style of course content presentation. Most students agreed that there was no problem with the exams itself, rather lack of appropriate student preparation for the exams was responsible for the low passing rates. Students acknowledged that it is essential in $\mathrm{MC}$ to attend the lectures and follow closely on the topics given rather than self-study or listening to lecture audio-records or reading student summaries. 
Table 3: Student opinions $(n=149)$ regarding types of learning barriers in medicinal chemistry courses

\begin{tabular}{|c|c|c|c|c|}
\hline Item & No & Yes & $\%$ No & $\%$ Yes \\
\hline Medicinal Chemistry is a dry topic & 89 & 60 & 59.7 & 40.4 \\
\hline $\begin{array}{l}\text { I cannot relate medicinal chemistry to the } \\
\text { pharmacy proficiency }\end{array}$ & 123 & 26 & 82.6 & 17.4 \\
\hline $\begin{array}{l}\text { My basic science information is weak to build } \\
\text { on it Medicinal Chemistry Knowledge }\end{array}$ & 101 & 48 & 67.8 & 32.2 \\
\hline $\begin{array}{l}\text { I did not complete / pass prerequisites for } \\
\text { medicinal chemistry }\end{array}$ & 130 & 19 & 87.2 & 12.8 \\
\hline $\begin{array}{l}\text { The course objective and learning outcomes } \\
\text { are unclear to me }\end{array}$ & 123 & 26 & 82.6 & 17.4 \\
\hline $\begin{array}{l}\text { The course objective and learning outcomes } \\
\text { are unclear to me }\end{array}$ & 132 & 17 & 88.6 & 11.4 \\
\hline
\end{tabular}

Table 4: Summary of the regression model obtained for the dependent variable, students' believe regarding MC being an important topic for their pharmacy profession $(n=149)$.

\begin{tabular}{lccc}
\hline Variable & Beta & $\mathbf{t}$ & $\boldsymbol{P}$-value \\
\hline Age & 0.147 & 1.462 & 0.148 \\
Gender & 0.054 & 0.583 & 0.561 \\
Pharmacy practice hours & -0.002 & -0.018 & 0.986 \\
Type of high school & -0.124 & -1.322 & 0.190 \\
MC is a dry topic & -0.409 & -4.251 & $\mathbf{0 . 0 0 0}$ \\
Basic science information is weak to build on it MC & -0.123 & -1.335 & 0.185 \\
Knowledge & & & 0.750 \\
Student did not complete/pass prerequisites for MC & 0.032 & 0.320 & $\mathbf{0 . 0 3 9}$ \\
Course objectives/learning outcomes are unclear & -0.202 & -2.094 & 0.527 \\
The tutors' teaching abilities failed to clarify the & -0.059 & -0.634 &
\end{tabular}

Output from a multivariable regression analysis in which 'students' believe regarding MC being an important topic for their pharmacy profession was the dependent variable. "Beta" is the standardized regression coefficient. The overall fit of the model was $R^{2}=0.225, p<0.001 . M C=$ medicinal chemistry

Students stated that the MC courses can be passed with daily study and good chemistry foundation. The organic chemistry courses prepare the student for the MC courses, but more focus on the basics (such as functional groups and heterocyclic chemistry) and more practice is required rather than having a large content with relatively less important information. Weakness in technical English language as well as basic chemistry knowledge were other faced issues. Regarding educational strategies, students asked for clearer, shorter more focused course summaries and handouts.

\section{DISCUSSION}

This study adds to the literature in the area of pharmaceutical education new data on students' perception towards the medicinal chemistry courses and the way it is taught. With over a quarter of the students agreeing to pursue a career or a postgraduate study related to medicinal chemistry, results of this study unveils important information for a better taught MC course in the future [11]. Students agree that medicinal chemistry is an important topic and studying it helps to better understand related topics in their pharmacy education but many reported failure of the current educational methodologies in meeting the stated objectives of the course.

Pharmaceutical education in Jordan is vital to the country. Jordan hosts more than twenty faculties of pharmacy, which offer graduates for both local and regional pharmacy needs. Hence, studies in the area of pharmaceutical education is highly beneficial. The importance of $M C$ in the pharmacy curriculum has been well acknowledge all over the world. But the high rate of failure goes on with little explanation. A recent study in Germany showed the relevance of organic chemistry to be highly important for the future of the pharmacy students, but the lack of motivation did not seem to be the explanation for high failure rates in organic chemistry courses [12].

This study explored barriers that could be leading to the high rates of failure in MC. Salman Amin Khan, an American educator who founded the Khan Academy, talked on "TED" about "Lets teach for mastery, not test scores" so the remaining $(47.3 \%)$ bring their lack of understanding of first-year topics such as general chemistry and organic chemistry and on these weak foundations we try to build MC, this could merit the failure in passing these courses [13]. Believing that $\mathrm{MC}$ is a dry topic and the weak 
basic science knowledge of the student were barriers in learning MC provided was weak to build on it MC. Pharmacy schools in Jordan need to investigate the relevance between the basic sciences and MC courses taught, especially since these courses are taught at different schools (the basic sciences and pharmacy schools respectively).

There are many strategies that could be followed to turn MC from a dry topic to an exciting rich topic. Games have been used to link MC with therapeutics in the real pharmacy world. Alsharif and colleagues made innovations in $\mathrm{MC}$ education relating drug structure knowledge to formulating therapeutic decisions [14]. Such strategies, and other new ones can be investigated in future research [15].

Majority of the students in this study agreed that medicinal chemistry is an important topic that helps in their better understanding of other related topics; for example, $58.4 \%$ of the students agree that studying pharmacology prior to $\mathrm{MC}$ helped them to better understand these courses. This suggests a need for a change in the sequence of courses in the pharmacy curriculum or at least as a module system.

However, with about half of the students declining from seeking a career related to medicinal chemistry, strategies to resolve the barriers towards learning $\mathrm{MC}$ are needed. It is well expected that pharmacy education is currently emphasizing on the clinical practice. Now, although that is highly important, it should not distract the educators from focusing on other, equally important courses in the pharmacy curriculum [16].

Gender differences has always been a key factor in exploring educational needs. Pharmacy is generally preferred by female high-school graduates due to their higher grades and the fact that pharmacy presents a socially acceptable career for females in the Arab world [6]. When it comes to education, a significantly higher proportion of males agreed with taking on the task of reading from a textbook or research paper and presenting it in class than females. Further research in this area is called for to reveal reasons behind such difference in choice between both genders.

Generally, students preferred the direct approach to learning MC, mainly via lectures. This could be due to lack of motivation to take on the role of an independent learner during the first years of higher education [17].
The English language can be a major barrier to many students in the Arab world. Only a third of the students enrolled at the Faculty of Pharmacy at $A S U$ received their high-school education in Jordan, leading to different English standards amongst the students. Majority of the students in this study rated their English language as intermediate to high, indicating that the language barrier was not the main issue hindering higher student pass rates [18].

The latest trend in pharmaceutical education points towards allowing the students to select the examination style that they feel best in assessing their capabilities in answering the intended learning outcomes of the course they study. Open book exams were the highest preferred method of assessment chosen by the students in this study, with the written assignments being second in line. Open book exams are not applied currently at the Faculty of Pharmacy at Applied Science Private University, and to the best of our knowledge, neither is it applied frequently at other Pharmacy schools in the country. We recommend to this student recommended assessment strategy, for the benefits it may hold within its application [19].

Considering the Focus group results, lecturer style in delivering the knowledge seems highly important in MC. Students acknowledged the important role of the lecturer in $\mathrm{MC}$, as self-study or listening to lecture audio-records or reading student summaries are not enough in this course [20]. However, students suggested focusing on the quality of the taught topics and the competency standards reached by the students rather than on the amount of material covered in the courses.

Recently, five cross-cutting abilities to be developed in the pharmacy students have been identified as professionalism, self-directed learning, leadership and advocacy, interprofessional collaboration and cultural competency [21]. In MC, many of these abilities can be targeted and achieved to some extent. Students' ability to self-directed learning can be targeted as the students work on building their abilities using their books and websites independently. Inter-professional collaboration and cultural competency can also be targeted, as the students work through the course with each other (during their group discussions). Professionalism, leadership and advocacy can be targeted through students having to make decisions, uncover and support their clinical judgments based on their MC knowledge. 
The promotion of students' critical thinking is important in creating pharmacy graduates with a knowledge base and competence level to deliver effective patient care. This study adds valuable information to the literature in this area, in that $M C$ in the fourth-year pharmacy curriculum can be incorporated in the mission towards improving the students' scholarly skills, knowledge, and interpretation towards the pharmacy profession.

\section{Limitations of the study}

This study is not without limitations with respect to general findings. The evaluation of the course was conducted in one pharmacy school in Jordan using one cohort of fourth-year pharmacy students. However, although the results generated from this study are limited to the study population and institution, it suggests that the MC course can be enhanced based on the students' perceptions revealed.

\section{CONCLUSION}

Students who perceived MC as a 'dry' topic with course objectives/learning outcomes that are not clear, are also of the opinion that this has negatively affected their view of $\mathrm{MC}$ as being an important topic for the pharmacy practice. Despite all the barriers revealed in this study regarding the study of $\mathrm{MC}$ courses, a number of students still look forward to pursuing a career in $\mathrm{MC}$ or continue with postgraduate studies related to $\mathrm{MC}$.

\section{DECLARATIONS}

\section{Acknowledgement}

The authors are grateful to the Applied Science Private University Amman, Jordan, for the financial support granted to this research project. The authors wish to thank the students who participated in the study.

\section{Conflict of interest}

The authors have no financial or other potential conflicts of interest with regard to this study.

\section{Contribution of Authors}

The authors declare that this work was done by the authors named in this article and all liabilities pertaining to claims relating to the content of this article will be borne by them.

\section{REFERENCES}

1. Jungnickel PW, Kelley KW, Hammer DP, Haines ST, Marlowe KF. Addressing competencies for the future in the professional curriculum. Am J Pharm Educ. 2009; 73(8): Article 156.

2. Nemire RE, Meyer SM. Educating students for practice: educational outcomes and community experience. Am J Pharm Educ. 2006; 70(1): Article 20.

3. Hepler CD, Strand LM. Opportunities and responsibilities in pharmaceutical care. Am J Hosp Pharm. 1990; 47(3): 533-543.

4. Accreditation council for pharmacy education. Accreditation standards and guidelines for the professional program in pharmacy leading to the doctor of pharmacy degree: effective July 1, 2007. [Cited 2018 January 20]. Available from: http://.acpe-accredit.org.

5. Kheir N, Zaidan M, Younes H, El Hajj M, Wilbur $K$, Jewesson PJ. Pharmacy Education and Practice in 13 Middle Eastern Countries. Am J Pharm Educ. 2008; 72(6): 133.

6. Al-Wazaify M, Matowe L, Albsoul-Younes A, Al-Omran OA. Pharmacy Education in Jordan, Saudi Arabia, and Kuwait. Am J Pharm Educ. 2006; 70(1): 18.

7. Faruk Khan MO, Deimling MJ, Philip A. Medicinal Chemistry and the Pharmacy Curriculum. Am J Pharm Educ. 2011; 75(8): 161.

8. Ganellin CR, Mitscher LA, Clement B, Kobayashi $T$, Kyburz E, Lafont $O$, et al. University education of medicinal chemists: comparison of eight countries. Eur J Med Chem. 2000; 35(1): 163-174.

9. World Medical Association. World Medical Association Declaration of Helsinki: ethical principles for medical research involving human subjects. JAMA. 2013; 310(20): 2191-2194.

10. Hodell C. ISD from the Ground Up: A no-Nonsense Approach to Instructional Design. In. 2nd ed: Alexandria, VA: ASTD Press; 2006.

11. Wollowitz S. Career Profile: Pharmaceutical Chemist. J Chem Educ. 2007; 84(10): 1585.

12. Wehle S, Decker M. Perception of the Relevance of Organic Chemistry in a German Pharmacy Students' Course. Am J Pharm Educ. 2016; 80(3): 40.

13. Khan S. Lets teach for mastery, not test scores; In: TedTalks. [Cited 2018 January 25]. Available from: https://www.ted.com/talks/sal_khan_let_s_teach_for_ma stery_not_test_scores.

14. Alsharif NZ, Galt KA, Mehanna $A$, Chapman $R$, Ogunbadeniyi AM. Instructional Model to Teach Clinically Relevant Medicinal Chemistry. Am J Pharm Educ. 2006; 70(4): 91.

15. Satyanarayanajois $S D$, Hill RA. Medicinal chemistry for 2020. Future Med Chem. 2011; 3(14): 1765-1786.

16. Barth BS, Bucholtz EC. Threaded Introductory Chemistry for Prepharmacy: A Model for Preprofessional Curriculum Redesign. J Chem Educ. 2017; 94(8): 10601065. 
17. Tsai CS. Using Computer Applications and Online Resources To Teach and Learn Pharmaceutical Chemistry. J Chem Educ. 2007; 84(12): 2019.

18. Khuwaileh AA, Shoumali AA. Writing Errors: A Study of the Writing Ability of Arab Learners of Academic English and Arabic at University. Lang Cult Curric. 2000; 13(2): 174-183.

19. Cook A, Leckey J. Do Expectations Meet Reality? A survey of changes in first-year student opinion. $J$ Further Higher Educ. 1999; 23(2): 157-171.
20. Blackie MAL, Case JM, Jawitz J. Student-centredness: the link between transforming students and transforming ourselves. Teach Higher Educ. 2010; 15(6): 637-646.

21. Jungnickel PW, Kelley KW, Hammer DP, Haines ST, Marlowe KF. Addressing competencies for the future in the professional curriculum. Am J Pharm Educ. 2009; 73(8): 156. 